\title{
Development of Rhyzopertha dominica (F.) (Coleoptera Bostrichidae) on durum wheat kernels and semolina
}

\begin{abstract}
The time necessary to larvae of Rhyzopertha dominica to drill kernels with or without dusts (semolina or debris from adults), and the possibility of development on semolina were evaluated. Tests were carried out on durum wheat kernels (Triticum durum Desfontaines), debris deriving from rearing, and semolina. Development was observed also on 0.5 and $6 \mathrm{~mm}$ of semolina and of debris. Thirty replicates were carried out for each test.

The number of first instar larvae, that successfully drill sound kernels within 10 days, was higher by adding semolina or debris. When only kernels were provided, the time needed to larvae to drill increased. Development and the number of emerging adults were not significantly influenced by the addition of semolina to the kernels. Larvae couldn't develop on $0.5 \mathrm{~mm}$, while an equal number of individuals completed the development to adult in $6 \mathrm{~mm}$ of semolina as in the tests with kernels. When development was on debris, a lower number of emerged adults was observed.
\end{abstract}

Riassunto - Sviluppo di Rhyzopertha dominica (F.) (Coleoptera Bostrichidae) su cariossidi e farina di grano duro

È stato valutato il tempo necessario alle larve di prima età di Rhyzopertha dominica per penetrare nelle cariossidi di grano duro (Triticum durum Desfontaines) in presenza $\mathrm{o}$ in assenza di semola o rosura dell'insetto e la possibilità di completare il ciclo su spessori di 0,5 e $6 \mathrm{~mm}$ di semola e rosura. Per ogni prova sono stati osservati trenta individui singolarmente.

Il numero di larve che penetra nelle cariossidi integre entro dieci giorni è maggiore in presenza di semola o rosura; in assenza di polveri aumenta il tempo necessario. Il tempo di sviluppo e il numero di adulti sfarfallato su cariossidi non varia in presenza o assenza di semola o rosura. Le larve non riescono a svilupparsi su un substrato con spessore di $0,5 \mathrm{~mm}$, mentre con $6 \mathrm{~mm}$ di semola il numero di adulti sfarfallati è analogo a quello osservato su cariossidi in assenza o presenza di semola; nel caso della rosura, si osserva un numero minore di adulti sfarfallati.

Key words: Lesser grain borer, cereal grain, flour, debris. 


\section{INTRODUCTION}

Rhyzopertha dominica (F.) is one of the most economically important beetles infesting kernels. Newly born larvae feed on dusts, produced by adults or deriving from food processing; then they drill kernels, where they complete the life cycle (Golebiowska, 1969). Larvae enter kernels within the first instar, a short time after egg hatching (Crombie, 1944), preferring breaks or the germ area where the covering testa is loose (Birch, 1945). According to Özkaya et al. (2009), larvae feed on both endosperm and germ. Osuji (1982) observed a faster development in larvae that entered the germ compared to the ones that entered through the endosperm.

The development from egg to adult is possible, when wheat kernels are damaged, with a $9 \%$ moisture content and temperatures between 26 and $36{ }^{\circ} \mathrm{C}$ (Birch, 1945). In sound kernels, with the same moisture content, development is possibile at $34^{\circ} \mathrm{C}$, while with a moisture content below $9 \%$ the lesser grain borer does not survive. The highest egg survival was observed at $30{ }^{\circ} \mathrm{C}$ and $75 \%$ R.H. and the lowest at $40{ }^{\circ} \mathrm{C}$ and $65 \%$ R.H. (Kumawat, 2007).

In mills and pasta factories, due to poor cleaning of machines and of processing departments, dusts, kernels, and pasta debris can accumulate and become breeding ground of pests. In this research the time necessary to larvae to drill kernels with or without dusts (semolina or debris from adults), and the possibility of development on semolina were evaluated.

\section{MATERIALS AND METHODS}

Laboratory cultures of Rhyzopertha dominica kept in a rearing room at $28 \pm 1{ }^{\circ} \mathrm{C}$, $70 \pm 5 \%$ U.R. and photoperiod of 16:8 (light:dark) were used for these tests. Eggs were collected according to Elek (1994) and incubated 7-8 days, in order to obtain first instar larvae, 0-24 hours old.

Tests were carried out on durum wheat kernels (Triticum durum Desfontaines), with debris deriving from rearing, and semolina. Debris were collected from rearing every two weeks, with a 30 mesh sieve and divided with 30,40, 50, and 70 mesh sieves. Debris presented $98,8 \%$ of particles size lower than 70 mesh $^{1}$. Semolina was sieved ${ }^{2}$ with the same procedure. Food substrate were kept at $-18{ }^{\circ} \mathrm{C}$ for 20 days, to remove possible infestations.

The substrate and a first instar larva were placed in a polypropylen cylinder ( $\varnothing: 14$ $\mathrm{mm}, \mathrm{h}: 11 \mathrm{~mm})$. Thirty replicates were carried out for each test.

(1) Percentage of particle size obtained from debris with sieves: 30 mesh $0.04 \% ; 40$ mesh $0.24 \%$; 50 mesh $0.92 \%$; 70 mesh $98.8 \%$.

(2) Percentage of particle size obtained from semolina with sieves: 30 mesh $0.1 \%$; 40 mesh 24.9\%; 50 mesh $37.5 \%$; 70 mesh $37.5 \%$. 


\section{Development on durum wheat kernels with semolina or debris}

In each cylinder, ten sound durum wheat kernels were placed, alone or with $3 \mathrm{mg}$ of one of the different fractions of semolina or debris. The amount of debris added was proportional to the quantity of dust produced by 40 adults in 10000 durum wheat kernels, in a week. Then, a first instar larva was added.

Different groups of 30 replicates were controlled after 1,2, 3, 4, 10 days to verify the time needed by larvae to drill and enter into the kernels.

A further group of 30 replicates for each substrate were observed until adults emergence. Adults emergence was controlled every three days.

Data were submitted to ANOVA and Duncan's multiple range test (SPSS.17).

\section{Development on different particle size of semolina or on debris}

In each cylinder 0.5 or $6 \mathrm{~mm}$ of semolina (30, $70 \mathrm{mesh})$ or debris were placed. First instar larvae were placed over $0.5 \mathrm{~mm}$ or in the middle of $6 \mathrm{~mm}$ substrate.

Thirty replicates, for each substrate and for each thickness, were controlled after 10 days, 30 replicates were observed until adult emergence. Adults emergence was controlled every three days.

Data were submitted to ANOVA and Duncan's multiple range test (SPSS.17).

\section{RESULTS}

\section{Development on durum wheat kernels with semolina or debris}

Larvae drilled durum wheat kernels within two days when different particle size of semolina were added; the number of larvae was the same with the different particle size (Tab. 1). A lower number of larvae was observed when debris were added to kernels. The lowest number of larvae, 21, and a longer period, from 1 to 10 days, was observed on durum wheat kernels without the addition of dust.

The number of individuals that became adult was constant in all the tests, with a $30 \%$ mortality (Tab. 2). Adults emerged between the $32^{\text {nd }}$ and the $35^{\text {th }}$ day from egg hatching, unless on clean kernels where the last emerged adult was observed on the $62^{\text {nd }}$ day.

\section{Development on different particle size of semolina or on debris}

First instar larvae placed in the cylinder with $0.5 \mathrm{~mm}$ of semolina or debris leaved the substrate and the few left larvae were not able to complete the development; when placed in the middle of a $6 \mathrm{~mm}$ substrate larvae remained in the substrate and survival was higher (Tab. 3).

An equal number of individuals completed the development to adult in $6 \mathrm{~mm}$ of semolina as in the tests with kernels. When development was on debris, a lower number of emerged adults was observed.

Emerging of adults was observed on semolina from the $23^{\text {rd }}$ day to the $35^{\text {th }}$ day; on debris emerging of adults started on the $35^{\text {th }}$ day and finished on the $47^{\text {th }}$ day (Tab. 4 ). 
Tab. 1 - Number of first instar larvae (30 replicates) of Rhyzopertha dominica $(F$.) entering durum wheat kernels, alone or with $3 \mathrm{mg}$ of semolina or debris, after 1, 2, 3, 4 and 10 days and mean period (days) (S.D.).

\begin{tabular}{|l|c|c|c|c|c|c|c|}
\hline \multirow{2}{*}{$\begin{array}{c}\text { Durum wheat } \\
\text { kernels }\end{array}$} & \multicolumn{5}{|c|}{ Number of larvae in the kernels } & \multirow{2}{*}{$\begin{array}{c}\text { Mean period } \\
\text { (Days) (S.D.) }\end{array}$} \\
\cline { 2 - 7 } & $\mathbf{1}^{\text {st }}$ & $\mathbf{2}^{\text {nd }}$ & $\mathbf{3}^{\text {rd }}$ & $\mathbf{4}^{\text {th }}$ & $\mathbf{1 0}^{\text {th }}$ & Total & \\
\hline + Semolina 30* & 25 & 4 & - & - & - & 29 & $1.1(0.35) \mathrm{b}$ \\
\hline + Semolina 40* & 25 & 4 & - & - & - & 29 & $1.1(0.35) \mathrm{b}$ \\
\hline + Semolina 50* & 27 & 2 & - & - & - & 29 & $1.1(0.26) \mathrm{b}$ \\
\hline + Semolina 70* & 25 & 4 & - & - & - & 29 & $1.1(0.35) \mathrm{b}$ \\
\hline + Debris & 24 & 0 & 0 & 2 & - & 26 & $1.2(0.81) \mathrm{b}$ \\
\hline Only kernels & 10 & 2 & 1 & 4 & 4 & 21 & $3.4(3.44) \mathrm{a}$ \\
\hline
\end{tabular}

ANOVA: $\mathrm{F}=11.818 \mathrm{P}<0.01$ Duncan's multiple range test.

* Semolina sieved with 30 or 40, 50, 70 mesh sieves.

Tab. 2 - Number of adults of Rhyzopertha dominica (F.) and mean period (S.D.) of adult emerging on durum wheat kernels, alone or with $3 \mathrm{mg}$ of semolina or debris.

\begin{tabular}{|l|c|c|c|c|c|}
\hline \multirow{2}{*}{ Durum wheat kernels } & \multicolumn{3}{|c|}{$\begin{array}{c}\text { Number of adults emerging } \\
\text { daily }\end{array}$} & \multirow{2}{*}{ N } & \multirow{2}{*}{$\begin{array}{c}\text { Mean period } \\
\text { (Days) (S.D.) }\end{array}$} \\
\cline { 2 - 5 } & $\mathbf{3 2}$ & $\mathbf{3 5}$ & $\mathbf{6 2}$ & Total & \\
\hline + Semolina 30* & 17 & 2 & - & 19 & $32.3(0.94)$ n.s. \\
\hline + Semolina 40* & 20 & - & - & 20 & $32.0(0.00)$ n.s. \\
\hline + Semolina 50* & 14 & 4 & - & 18 & $32.2(0.77)$ n.s. \\
\hline + Semolina 70* & 19 & 2 & - & 21 & $32.3(0.90)$ n.s. \\
\hline + Debris & 17 & 1 & - & 18 & $32.2(0.70)$ n.s. \\
\hline Only kernels & 18 & 0 & 1 & 19 & $33.6(6.88)$ n.s. \\
\hline
\end{tabular}

ANOVA: F=0.739 P=0.596 Duncan's multiple range test.

* Semolina sieved with 30 or $40,50,70$ mesh sieves.

Tab. 3 - Number of first instar larvae of Rhyzopertha dominica (F.) alive or escaped after 10 days on different particle size of semolina or debris (thick 0.5 and $6 \mathrm{~mm}$ ).

\begin{tabular}{|l|c|c|c|c|}
\hline \multirow{3}{*}{ Substrate } & \multicolumn{4}{|c|}{ Thickness (mm) } \\
\cline { 2 - 5 } & \multicolumn{2}{|c|}{$\mathbf{0 . 5}$} & \multicolumn{2}{c|}{$\mathbf{6}$} \\
\cline { 2 - 5 } & Alive & Escaped & Alive & Escaped \\
\hline Semolina 30* & 12 & 10 & 22 & 0 \\
\hline Semolina 70* & 13 & 9 & 22 & 0 \\
\hline Debris & 17 & 7 & 20 & 0 \\
\hline
\end{tabular}

* Semolina sieved with 30 and 70 mesh sieves. 
Tab. 4 - Number of adults of Rhyzopertha dominica (F.) and mean period (S.D.) of adult emerging on semolina of durum wheat kernels (thick $6 \mathrm{~mm}$ ).

\begin{tabular}{|l|c|c|c|c|c|c|c|c|c|c|c|}
\hline \multirow{2}{*}{ Substrate } & \multicolumn{7}{|c|}{ Number of adults emerging daily } & \multirow{2}{*}{ N } & \multirow{2}{*}{$\begin{array}{c}\text { Mean period } \\
\text { (Days) (S.D.) }\end{array}$} \\
\cline { 2 - 12 } & $\mathbf{2 3}$ & $\mathbf{2 6}$ & $\mathbf{2 9}$ & $\mathbf{3 2}$ & $\mathbf{3 5}$ & $\mathbf{3 8}$ & $\mathbf{4 1}$ & $\mathbf{4 4}$ & $\mathbf{4 7}$ & & \\
\hline Semolina 30* & 1 & 9 & 8 & 1 & 1 & - & - & - & - & 20 & $27.8(2.65) \mathrm{b}$ \\
\hline Semolina $70 *$ & 4 & 9 & 7 & - & - & - & - & - & - & 20 & $26.4(2.23) \mathrm{b}$ \\
\hline Debris & 0 & 0 & 0 & 0 & 4 & 3 & 3 & 3 & 2 & 15 & $40.2(4.31) \mathrm{a}$ \\
\hline
\end{tabular}

ANOVA: $\mathrm{F}=100.221 \mathrm{P}<0.01$ Duncan's multiple range test.

* Semolina sieved with 30 and 70 mesh sieves.

\section{CONCLUSIONS}

In this research, at $28^{\circ} \mathrm{C}$ and $70 \%$ R.H., first instar larvae of Rhyzopertha dominica were able to drill sound durum wheat kernels, differently from the observation of Howe (1950) on wheat. Development and the number of emerging adults were not significantly influenced by the addition of semolina to the kernels. The number of first instar larvae, that succesfully drilled sound kernels within 10 days, was higher adding semolina or debris. Almost all first instar larvae penetrated within the second day when semolina was added; the time increased when only kernels were provided.

In the tests with $0.5 \mathrm{~mm}$ semolina, first instar larvae could not develop or fled. In tests with $6 \mathrm{~mm}$ semolina, the number of emerging adults was the same as the one observed on kernels and the development period was shorter, while with $6 \mathrm{~mm}$ debris a longer development period and a lower number of emerging adults were observed. In tests carried out with semolina, due to the small granulation, Klys (2006) observed no population development as adults showed a scarce mobility, turned over and starved.

The mean period of development was shorter on semolina than on kernels. First instar larvae inside the kernels became adults in 32 days, while larvae reared on semolina developed to adults in 27 days.

First instar larvae placed in the middle of $6 \mathrm{~mm}$ of debris took 40 days to emerge as adults. Howe (1950), observed development faster on wheat kernels than the one on wheat flour, but during the experiment the substrates were repeatedly sieved, disturbing larvae, while in these tests the emerging of adults was verified without sieving the substrate.

\section{REFERENCES}

BIRCH L.C., 1945 - A contribution to the ecology of Calandra oryzae L. and Rhyzopertha dominica Fab. in stored wheat. - Trans. R. Soc. South Australia 69 (1): 140-149.

CROMBIE A.C., 1944 - On intraspecific and interspecific competition in larvae of graminivorous insects. - J. exp. Biol. 20 (2): 135-151.

ELEK J. A., 1994 - Methods for collecting eggs and monitoring egg-hatch and immature development of Rhyzopertha dominica (F.) (Coleoptera: Bostrichidae). - J. Stored Prod. Res. 30 (4): 261265. 
Golebiowska Z., 1969 - The feeding and fecundity of Sitophilus granarius (L.), Sitophilus oryzae (L.) and Rhyzopertha dominica (F.) in wheat grain. - J. Stored Prod. Res. 5: 143-155.

Howe R.W., 1950 - The development of Rhyzopertha dominica (F.) (Col., Bostrichidae) under constant conditions. - Ent. Monthly Mag. 86: 1614-1618.

KŁYS M., 2006 - Nutritional preferences of the lesser grain borer Rhizopertha dominica (F.) (Coleoptera, Bostrichidae) under conditions of free choiche of food. - J. Plant Prot. Res. 46 (4): $359-368$.

KumawAT K.C., (2007) - Effect of abiotic factors on biology of Rhyzopertha dominica (Fab.) on wheat. - Ann. Plant Prot. Sci. 15 (1): 111-115.

Osus F.N.C., 1982 - Development of the lesser grain borer, Rhyzopertha dominica, in maize kernels as affected by site of larval entry. - Ent. Exp. \& appl., 31: 391-394.

ÖZKAYA H., ÖZKAYA B., COLAKOGLU A.S., 2009 - Technological properties of a variety of soft and hard bread wheat infested by Rhyzopertha dominica (F.) and Tribolium confusum du Val. - J. Food, Agric. \& Env. 7 (3-4): 166-172.

Lidia Limonta, Matteo Carlo Morosini, Daria Patrizia Locatelli - Dipartimento di Protezione dei Sistemi Agroalimentare e Urbano e valorizzazione delle Biodiversità- DiPSA, Università degli Studi di Milano,Via Celoria 2, 20133 Milano - Italy.E-mail: lidia.limonta@unimi.it 